\title{
Agronomic biofortification through micronutrient management in maize: A review
}

\author{
Augustine $\mathbf{R}^{*}$ \\ Department of Agronomy, Faculty of Agriculture, Annamalai University, Chidambaram (Tamil \\ Naidu), India \\ D Kalyansundaram \\ Department of Agronomy, Faculty of Agriculture, Annamalai University, Chidambaram (Tamil \\ Naidu), India \\ * Corresponding author. E. mail: augustinerajendran@gmail.com
}

\section{Article Info}

https://doi.org/10.31018/

jans.v12i3.2356

Received: August 9, 2020

Revised: September 5, 2020

Accepted: September 9, 2020

\section{How to Cite}

Augustine R. and Kalyansundaram, D. (2020). Agronomic biofortification through micronutrient management in maize: A review. Journal of Applied and Natural Science, 12(3): 430 - 437. https://doi.org/10.31018/jans.v12i3.2356

\begin{abstract}
Most of the health components based foods are boosted by the application of mineral nutrients. Since post green revolution, farmers fertilize the crop for optimum to higher yields which are often overlooked. In addition to higher yield, plant nutrition also affects other human nutritional needs like proteins, oils, vitamins and minerals. Trace elements necessary to human nutrition can be optimized by applying to food crops. Due to various factors like temperature, climate, time of applications, crop adaptability, etc., some nutrients have their own restrictions, and few micronutrients are beneficial and play a significant role in food nutrition making easier access in the plant edible parts by its applications. It is important to note that the foliar application of $\mathrm{Zn}$ and $\mathrm{Fe}$ at the later crop stage (mid booting stage or early milking stage) is found to be effective than early applications. When compared to related interventions like supplementation and fortification, biofortification was found to be significantly costeffective in applications to crop and create values for human nutrition.
\end{abstract}

Keywords: Biofortification, Iron (Fe), Micronutrients, Supplementation, Zinc (Zn)

\section{INTRODUCTION}

Maize is the third most important food crop next to wheat and rice. India is among the top 10 maize producers in the world and contributes around $2-3 \%$ of the total global production and is among the top 5 maize exporters in the world contributing $14 \%$ of the total maize exported to various countries around the world. Maize is an important cereal crop of India for a larger section of populations, the raw material for industries and feed for animals and plays a major role in agrobased economy. Maize is consumed as basic food in some of the major countries as, corn flakes, corn syrup and oil. For animal feed, its feed value from grain, leaf and stem is gaining more importance in many countries. For industrial and pharmaceutical applications, it can be used to produce starch, ethanol, plastics and as a base product for antibiotic production. Starch is the main product of maize used in industries for manufacturing dextrin, liquid glucose, modified starches, maltose, etc. (Peter et al., 2014; Malhotra, 2017: Bushra, et al., 2019).
In recent decades, because of its importance maize area has been steadily increasing or remaining stable in the maize producing countries. Maize processing industries encourages farmers to enhance the cultivable area under maize in order to sell the maize as a cash crop. Maize is an exhaustive crop having high potential than other cereals and also absorbs a huge quantity of nutrients from the soil at different growth stages of the crop (Rafael et al., 2013). The biggest user of maize in India is the poultry industry, with $49 \%$ of the share, followed by human consumption at $23 \%$. Other usages include cattle feed $(12 \%)$ and industrial (starch) products (15\%) followed by the food and beverage industry with a 1\% share each (Dass 2013; USDA 2013; Malhotra, 2017).

Normal maize has poor nutritional value because of poor contents of essential amino acids, such as lysine and tryptophan. But quality protein maize contains a higher amount of these amino acids in the endosperm than normal maize. The productivity of quality protein maize is low due to inherent low soil fertility and poor 
nutrient management practices, and no use of secondary and micronutrients (Firoz et al., 2019). The integrated use of organic manure and chemical fertilizers can augment the nutrient use efficiency and also enhance the productivity of quality protein maize (Singh et al., 2020). The balanced combination of amino acids in quality protein maize has resulted into its higher biological value ensuring more availability of protein to both human and animal as compared to normal maize (Chaudhary et al., 2012; Boddupalli et al., 2019).

Biofortification is one such unique practice done through fertilization with nutrients and has been extensively used in maize with supplemental foliar spray for increasing the high concentrations of nutrients in the grain. Even though this practice is common in crops, spraying minerals at the appropriate time during plant growth turns to an efficient nutritional starter/gainer in plant parts which helps in direct nutritional support to human population and animals, etc. (Garg et al., 2018).

\section{WHY BIOFORTIFICATION?}

Billions of deprived people worldwide suffer from varied physical disabilities due to (micronutrient malnutrition) insufficient supply of nutrients, amino acids, vitamins and minerals. India is also one such country where a huge malnourished people are identified which needs quick interventions. The problem of micronutrient deficiencies arises in developing countries where the rural population are totally dependent on cereal-based diet as a staple food (Prasad et al., 2014).

Essential human nutrition is protein, lysine, tryptophan, iron, zinc, vitamin A and vitamin C, and their deficiency will lead to various health disorders. Similarly, antinutritional compounds such as erucic acid, glucosinates and Kunitz trypsin inhibitor (KTI) consumed at high concentration levels will lead to complication in the health of humans and livestock (Pfeiffer and McClafferty, 2007; Gupta et al., 2015; Devendra et al. 2018).

The most cost-effective and sustainable technique to overcome the nutritional problem, is by enriching nutrients in staple food through biofortification. Biofortification plays a crucial role in reducing the gap between the micronutrient requirements and increased intake of three micronutrient dietaries, Vitamin A, Iron and Zinc which is of public health significance worldwide. The Biofortified crops are delivered with enriched nutrients to rural communities or the lower income group, where commercial fortification or supplementation is not accessible. The primary targets of biofortification are the women and children, where their requirements are high and this often goes as unmet (Graham and Cakmak, 2015).

The challenge remains, is to deliver nutritious, safe and cost-effective food to help improve the impact of nutritional security. Various interventions like supplementation diet and dietary diversification has been tried to alleviate micronutrient deficiencies, and to be specific, none of these approaches was found to be quietly effective, because of its poor distribution system and infrastructure and expensive (Tanumihardjo et al., 2007; Francesco et al., 2011).

Plants are capable of synthesizing essential dietary micronutrients and act as a biochemical storage house. The plant-based foods consumed abundantly from rice, wheat, cassava and maize by populations contains several micronutrients that are insufficient to meet daily nutritional requirements. These nutrients are unevenly distributed in plant parts. For example, iron and provitamin carotenoids content is high in rice leaves but low in polished grain and similarly high in wheat bran and low in polished wheat flour. Biofortification efforts are directed towards increasing levels of micronutrients in edible tissues of crops by integrating crop management practices and genetics and breeding approaches (Chavali and Seetharam, 2017).

\section{IMPORTANCE OF BIOFORTIFICATION THROUGH FERTILIZATION}

The effective role of fertilizers is to provide nutrients to plants in order to grow, mainly with Nitrogen, Phosphorus and Potassium. This approach has an advantage, because it works faster. But for a long-term strategy focussing on improving human health, there found to be a serious limitation with enhanced fertilizers. They are costly and expensive and need to be applied continuously. The potential of biofortified crops is to provide a continuous supply of micronutrients to large populations with cost effective and easily accessible (Stein et al., 2006; Meenakshi et al., 2010; Adnane Bargaz et al., 2018; Carla et al., 2019). Continued technical developments combined with economic savings, biofortification focuses on the path of "nutritional security" (Shetty, 2009). The importance of biofortification noted by (Valenca et al., 2017; Chavali and Seetharam, 2017) are:

Priority in selective nutrition: Biofortification allows selected nutrition to a particular crop, either by genetic or breeding or agronomic approach. This method of approach reduces the drudgery of consuming multiple foods so that required nutrients are incorporated in the crop. Ex., Fortification of Golden rice with vitamin A, so that poor people can consume nutritious food and Orange sweet potato for Vitamin A which yielded significant results in mothers and children.

Need for overspending on food: In developing poor countries, people could not afford to spend on nutritious food, for which biofortification gives a rescuing hand. Since nutrition is focussed on a single source, 
people need not spend on multiple foods. Lots of money can be saved and been used for their welfare activities.

Increase in human productivity: Due to lack of nutrients, there is a reduction in efficiency in human workforce output. Substitution with nutrients in an efficient manner can improve productivity, which contributes to economic and social growth and development. Biofortification is a multistage process which requires evaluation at every step and finally judged by the people/populations. Biofortification has many advantages in nutritional interventions. For ex., In heart disease, researchers must wait for decades to conclude if diet brings any difference. So they decided to measure the intermediate points, not the final outcomes. Heath consequences of malnutrition emerge quickly, like anaemia in women, blindness in children and early death. Only biofortified food crops can make a difference, and these developments and improvements will appear quickly in the coming years ( Garg, 2018).

Biofortification through foliar fertilization is a new technique extensively used in maize because of the introduction of hybrids with the high increased use of fertilizers containing high concentrations of nutrients with the target levels of micronutrients. Keeping in view the growing importance of maize as food and feed, biofortification of maize includes enrichment of micronutrients like provitamin $\mathrm{A}, \mathrm{Fe}$ and $\mathrm{Zn}$ in grain, which plays a significant role in the human health system (Kumar et al., 2019).

\section{MICRONUTRIENT IN HUMAN NUTRITION}

Micronutrient deficiency-related health issues or problems are more prevalent in both urban and rural areas. Under present scenario, three billion people around the globe are deficient in vitamins, minerals, specifically vitamin A, lodine (I), iron (Fe) and Zinc (Zn) (Dahiya et al., 2008). This is due to lack of awareness about dietary practices, poverty, and lack of affordability towards balanced foods, which leads to micronutrient deficiency.

Vitamin A: Plays an essential role in vision, immune response, bone growth, reproduction, embryonic development and regulation of adult genes. An early symptom of Vitamin A deficiency is night blindness. According to the World Health Organization, around 2.5 - 5.0 lakh children are becoming blind every year and half of which die within a year of losing sight. Since humans and animals cannot synthesize vitamin $A$ in their body, the only source achieved is through dietary means. In rural poor populations, plant foods are generally preferred than animal products, because of its rich source of provitamin A carotenoids. As a vitamin $A$ supplement, $\beta$ - Carotene rich maize is found efficient when consumed as a staple food when com- pared to other commercial fortified products (Gannon et al., 2014).

lodine: It is a component of thyroid hormones. lodine deficiency disorders lead to the greater cause of preventable brain damage in the foetus and infants and retarded psychomotor development in young children. It is estimated that more than one billion individuals suffer from goitre worldwide, out of which half of them from Asia are worst affected (Creswell et al., 2018).

Iron: An active constituent of the catalytic site of heme and non-heme proteins. More than one-third population suffers from anaemia out of which half of is by iron-deficiency. Iron deficiency affects cognitive development, resistance to infection, slows work productivity, dizziness and pregnancy, etc. Children of anaemic mothers have low iron reserves and require more iron than supplied by breastfeeding. It is estimated around 8 lakh deaths annually are attributed to iron deficiency anaemia (James and Balk, 2019).

Zinc: It is involved in RNA and DNA synthesis and is a constituent of zinc-containing enzymes mainly for its cellular growth. One-third of the population is at high risk due to zinc deficiencies. Zinc deficiency leads to impaired growth, immune dysfunction, increased mortality and abnormal neurobehavioral development. Zinc deficiency is directly related to the severity and frequency of diarrhoea in children causing even death (Cakmak and Kutman, 2018).

In contrast, Fe and $\mathrm{Zn}$ is an important nutritional problem specifically in developing countries like India and Africa, which needs genetic and agronomic biofortification of food crops by enriching with $\mathrm{Fe}$ and $\mathrm{Zn}$ (other micronutrients) in grains or plant parts. Although it's very simple and cost less, the application of essential micronutrients is complicated due to method of application, soil fertility, and mineral mobility in the plant and its accumulation in different sites (Zhu et al., 2007). This strategy has been successful in limited levels within specific locations only. Increasing the concentration of micronutrients in staple crop is the first step in making a rich source of nutrition for human (Prasad et al., 2014).

\section{AGRONOMIC BIOFORTIFICATION OF MAIZE}

Agronomic biofortification can provide temporary increase in micronutrient through fertilization enhancement in productive parts. Maize is one of the major staple crops with a variety of uses. Maize owes worldwide significance due to its utilization in human food and livestock feed. Use of maize as human food and animal feed has led to the increased productivity and rise in fertilizer applications and thus enhances the soil depletion and loss of phyto-availability mineral (Raut et al., 2010; Lal, 2009). Due to this, mineral deficiencies have become a critical (limiting) factor in 
productivity and quality of the crop.

Among the Biofortification methods, application of fortified fertilizers with micronutrients is the cost-effective and simplest method, and the success of agronomical biofortification is highly variable due to its mineral mobility, its accumulation and soil compositions in the specific locations. Soil composition analysis has indicated that $1 / 2$ of the agricultural soils are $\mathrm{Zn}$ deficient. Agronomic Biofortification is cost-effective and laborious as it demands continuous micronutrient application to the soils or plants. Biofortification by Fe foliar spray in rice crops was an effective way to improve iron concentration in rice grains (Fang et al., 2008; He at al., 2013; Yuan et al., 2013; Roman et al., 2019).

Micronutrient fertilizers should be applied regularly and are costly and environmentally biased. Overall such strategies are applied to specific crops with the mineral potentiality to boost the nutritional quality of foods. In general staple crop, grains have very low bioavailable levels of $5 \%$ total $\mathrm{Fe}$ and $25 \%$ total $\mathrm{Zn}$ (Bouis and Welch, 2010). Mainly the presence of antinutrients in plant foods plays a significant role in reducing the bioavailability of essential micronutrients (Graham et al., 2001). Following are the antinutrients, which reserve the function of micronutrient bioavailability in plant parts (Table 1).

Further, it is not always possible to target the edible portion of plant parts like seed or fruit. It even results in the accumulation of nutrients in leaves or non-edible portions of plants. Therefore this technique is successful with certain minerals under specific crops/species. In addition, fertilizer accumulation in soil and water poses adverse environmental effects (Garg et al., 2018).

Agronomic Biofortification which includes fertilization, can boost the Fe, Zn, I and Se levels in foods. Deficiencies of I and Se does not limit the crop growth, whereas correction of $\mathrm{Fe}$ and $\mathrm{Zn}$ deficiency can benefit both crops and consumers. Timing of foliar application of micronutrients is found to be critical besides following agronomic practices in maximizing micronutrient accumulation of $\mathrm{Zn}$ and Fe. Application of $\mathrm{Zn}$ and $\mathrm{Fe}$ is a complementary solution to plant breeding, and both are required for better efficacies (Graham, 2018).

\section{ROLE OF MINERAL FERTILIZATION ( $\mathrm{Zn}$ and $\mathrm{Fe}$ ) IN MAIZE CROP}

Minerals are essential for plant growth, reproduction and nutrient deficiencies which limit the yield potential and plant products, that contributes an important source of minerals in the human diet (Kumar et al., 2015). Application of $\mathrm{Zn}$ and Fe fertilizers is a shortterm solution and act as complementary to plant breeding. In addition, it appears that improving the nitrogen nutritional status of plants promotes the accumulation of $\mathrm{Fe}$ and $\mathrm{Zn}$ in grain (Cakmak, 2010; White and Broadley, 2011; Monica et al., 2014).

For instance, a positive and highly significant correlation between $\mathrm{Fe}$ and $\mathrm{Zn}$ concentrations had been observed in many crops (Gregorio et al., 2000; Ozkan et al., 2007; Velu, 2013). Such correlations among micronutrients indicate that improvement in one element may simultaneously improve the concentration of other elements (Ozkan et al., 2007). Both Fe and Zn interact positively with $\mathrm{N}$, and inversely with $\mathrm{P}$. A positive $\mathrm{N} x$ $\mathrm{Zn}$ interaction in cereals was reported by a number of researchers (Prasad et al., 2014). This is due to improvement in root uptake and translocation of $\mathrm{Zn}$ due to nitrogen (Kutman et al., 2010; Prasad et al., 2014). Fe and $\mathrm{Zn}$ application are utmost important and in the specific foliar application help in absorption and control of deficiency. This was found to be the best method for biofortification in maize crop.

Iron is transported around the plant in a chelated form, mainly as citrate and malate in xylem and nicotianamine (NA) synthase and its derivatives in the phloem. In plants, iron is stored in the form of ferritin. Plant ferritin gene has been overexpressed in wheat, rice and maize, using endosperm as specific promoters. As stated earlier, the bioavailability of iron is low $(<15 \%)$ in plant foods and thus an important factor need to be considered in biofortification approach in staple crops like maize. Hence targeting iron specifically in the endosperm is an alternative solution to the antinutrient (phytate) problem (Connorton et al., 2017).

The removal of antinutrients from plants increases bioavailable mineral content. Phytic acid (also known as phytate) is an antinutrient that chelates minerals and reduces the bioavailability in the gut (Denbow et al., 1998). An expression of iron-storage protein and phytase (a fungal enzyme that breaks down phytate) has been achieved in rice and maize with a combined approach (Drakakaki et al., 2005). This combined mineral biofortification will provide maximum levels of bio-

Table 1. Influence of antinutrients against essential micronutrients.

\begin{tabular}{lc}
\hline Antinutrients & $\begin{array}{l}\text { Essential micronutrients } \\
\text { reserved }\end{array}$ \\
\hline Phytic acid & $\mathrm{Fe}, \mathrm{Zn}, \mathrm{Cu}, \mathrm{Ni}$ \\
$\begin{array}{l}\text { Cellulose, hemicelluloses, } \\
\text { lignin, cutin, suberin } \\
\text { Tannins and Polyphenols }\end{array}$ & $\mathrm{Fe}, \mathrm{Zn}, \mathrm{Cu}$ \\
Lectins & $\mathrm{Fe}$ \\
$\begin{array}{l}\text { Goitrogens } \\
\text { Heavy Metals (e.g., Cd, } \\
\text { Hg, Pb) }\end{array}$ & $\mathrm{Fe}, \mathrm{Zn}$ \\
\hline Source: Philip and Martin (2005) & \\
\end{tabular}


available iron.

Iron is required for the synthesis and stabilization of chlorophyll, which is why the chlorophyll content significantly decreases in Fe-deficient plants. As a result, iron deficiency has a market effect on plant growth and product quality (Gyana and Sunita, 2015). A foliar application of 2-3\% Fe concentration in Fe-deficient soils increases $\mathrm{Fe}$ level in crops and improves yield, applied at different intervals. When applied in excess, Fe fertilization remains complicated and has a strong reaction towards insolubility. These are expensive and improper applications leads to environmental hazards. Iron deficiency affects more than two billion people, which directs to consider ( $\mathrm{Fe}$ ) mineral as a priority in maize biofortification. Iron has low mobility in soil, and due to this, the foliar application is recommended with $\mathrm{FeSo}_{4}$ and the Fe-EDDHA chelates and Fe-EDTA for better absorption (Frossard et al., 2000; Zhu et al., 2007). Translocation of foliar-applied iron may be enhanced by chelation and by treatment with $\mathrm{GA}_{3}$ or kinetin. In corn, ferrous sulphate with chelating agents (EDTA or DTPA) considerably increased the translocation of iron out of the treated leaf (Ferrandon and Chamel, 1989; Gyana and Sunita, 2015).

The ideal $\mathrm{Fe}$, provided in the chelate form is more available and effective against Fe deficiency, which is quite expensive and found to be marginally better in increasing $\mathrm{Fe}$ concentration in grain. Foliar application of ferrous sulphate $\left(\mathrm{Fe}_{2} \mathrm{So}_{4}\right)_{3}$ has shown a better effect than soil application in increasing $\mathrm{Fe}$ concentration in cereals (grain), which also enhances the yield of crops. Iron, when used under process fortification, has been successful for Fe fortification which includes rice, fish, soy sauce, wheat flour \& maize flour, milk and infant formulas (Flora et al., 2019).

Zinc has diverse physiological functions in biological systems (Krezel and Maret, 2016). Zinc ( $Z n$ ) is the most abundant element next to iron and is an essential micronutrient for plants. The fertilization of crop with $\mathrm{Zn}$ either through soil or foliar application is a common practice in agriculture crop/soil where $\mathrm{Zn}$ deficiency plays a critical role in crop productivity. The main focus is to correct $\mathrm{Zn}$ deficiency and improve the yield with more attention paid from the human nutritional perspective towards the presence of $\mathrm{Zn}$ concentration in the edible parts of seeds or grains or starchy roots. Usually, soil applications of $\mathrm{Zn}$ had little effect on the $\mathrm{Zn}$ concentration in grain, whereas foliar $\mathrm{Zn}$ sprays were quiet effective in $\mathrm{Zn}$ accumulation in grains. Foliar $\mathrm{Zn}$ applications in wheat and rice are quite effective in enriching the grain with $\mathrm{Zn}$ if they are applied at a later stage than on earlier developmental stage, preferably during grain-filling (Cakmak et al., 2010a; Boonchuay et al., 2013; Abdoli et al., 2014; Cakmak and Kutman, 2018). Foliar application of zinc fertilizer in wheat grain increases grain zinc concentration by up to $20 \mathrm{ppm}$ in India and Pakistan (Zhou et al., 2012) and in rice up to $27 \%$ (Cakmak and Kutman, 2018). Foliar applications of zinc at reproductive stages of crop development are most effective at increasing the amount of zinc accumulated in the grain of staple cereal crops such as wheat. Using both soil-applied zinc fertilizers and foliar sprays results in the maximum accumulation of zinc in grains (Yang et al., 2011; Miller and Welch, 2013).

Zinc fertilizers have been widely used to enhance the crop yield and to increase $\mathrm{Zn}$ concentration in grains by various (broadcasting, foliar spray, banding and in combinations) methods (Rehim et al., 2014; Imran et al., 2015; Sarwar et al., 2015; Imran and Rehim, 2017). Foliar spray of $Z n$ improved grain yield and increased Zn and starch contents (Imran et al., 2016).

The foliar application of $\mathrm{Zn}$ was effective against reducing phytate (antinutrient) concentration in grain ( Cakmak et al., 2010; Cakmak and Kutman, 2018). The bioavailability of $\mathrm{Zn}$ in diets is promising based on phytate/Zn molar ratio. In general, foliar $\mathrm{Zn}$ applications are Zinc Sulphate $\left(\mathrm{ZnSo}_{4}\right)$ and EDTA - Chelated $\mathrm{Zn}$. For correcting $\mathrm{Zn}$-deficiency, Chelated $\mathrm{Zn}$ is superior to $\mathrm{ZnSo}_{4}$, but the cost-effective option should be compared with high priced Zn-EDTA. Above all, the timing of foliar Zn-application is more important to determine the effectiveness in biofortification (Dennis and Welch, 2013; Cakmak and Kutman, 2018). Agronomic efficiency of $\mathrm{Zn}$ as the foliar application was four times higher than soil applications and also the rate of application was lower when applied as a foliar spray (Dhaliwal et al., 2010). The dosage rate of 25 to $50 \mathrm{~kg}$ $\mathrm{ZnSO}_{4}$ per ha is generally proposed for use in fertilization of soils/crops with Zn deficiency (Cakmak, 2008). Depending on the severity of the Zinc deficiency problem, a cost-effective model in fertilization needs to be worked out, to understand the better practices adopted in the region. At the initial stage, farmers need to be motivated about the strategy of Agronomic Biofortification use in staple crops, quality seeds and awareness about the Zinc nutrition to human health (Cakmak and Kutman, 2018). This will bring a potential growth in fertilization (biofortification) of $\mathrm{Zn}$ as a foliar spray or foliar + soil application, irrespective of stages it reaches for maintaining yield and helps in accumulation of available $\mathrm{Zn}$ in grain. Thus enriched micronutrient (Fe and $\mathrm{Zn}$ ) in maize overcomes malnutrition, which holds immense quality for sustainable and cost-effective solutions (Maqbool and Beshir, 2019).

\section{Conclusion}

Agronomic biofortification is the simplest and fastest way for biofortification of grains with $\mathrm{Fe}, \mathrm{Zn}$ or other micronutrients, where cereals are mainly the staple 
food in developing countries. This is an alternate route to reach the rural poor populations, who cannot afford to buy mineral supplements nor can afford to improve the diet components. Although nutrients present in the soil, their availability of plant roots is limited, because of complicated soil processes and conditions, the foliar application can help faster and higher absorption rate and cure deficiency symptoms. Thus, the foliar application can be an effective method in biofortification of crops. Adequate $\mathrm{Fe}$ and $\mathrm{Zn}$ fertilization are necessary when GM cultivars with improved $\mathrm{Fe}$ and $\mathrm{Zn}$ are developed. Thus, genetic and agronomic approaches are complementary to each other and should progress in tandem. However, a better understanding of micronutrient reactions, their absorption and translocation in plants, specifically to grains, is required.

\section{ACKNOWLEDGEMENTS}

The authors gratefully acknowledge the advice and guidance provided by $\mathrm{Dr} \mathrm{M}$. Ganapathy, Professor and Head, Department of Agronomy, Faculty of Agriculture, Annamalai University, Chidambaram. Tamilnadu. India.

\section{Conflict of interest}

The authors declare that they have no conflict of interest.

\section{REFERENCES}

1. Abdoli, M., Esfandiari, E., Mousavi, S. B. and Sadeghzadeh, B. (2014). Effects of foliar application of zinc sulfate at different phenological stages on yield formation and grain zinc content of bread wheat (cv. Kohdasht). Azarian Journal of Agriculture, 1: 11-16.

2. Adnane Bargaz, Karim Lyamlouli, Mohamed Chtouki, Youssef Zeroual, and Driss Dhiba. (2018). Soil Microbial Resources for Improving Fertilizers Efficiency in an Integrated Plant Nutrient Management System. Frontiers in Microbiology. 9: 1606.

3. Valenca de, A.W., A. Bake, I.D. Brouwer and K.E. Giller. (2017). Agronomic Biofortification of crops to fight hidden hunger in sub-Saharan Africa. Global Food Security 12: 8 $-14$

4. Boddupalli, M., Prasanna, Natalia Palacios-Rojas, Firoz Hossain, Vignesh Muthusamy, Abebe Menkir, Thanda Dhliwayo, Thokozile Ndhlela, Felix San Vicente, Sudha K. Nair, Bindiganavile S. Vivek, Xuecai Zhang, Mike OIsen, and Xingming Fan. (2019). Molecular Breeding for Nutritionally Enriched Maize: Status and Prospects. Frontiers in Genetics, 10: 1392.

5. Boonchuay, P., Cakmak, I., Rerkasem, B. and Prom-UThai, C. (2013). Effect of different growth stages on seed zinc concentration and its impact on seedling vigour in rice. Journal of Soil Science \& Plant Nutrition, 59: 180188.

6. Bouis, HE. and Welch, RM. (2010). Biofortification-a sustainable agricultural strategy for reducing micronutrient malnutrition in the global south. Crop Sci., 50:S20-S32

7. Bushra Huma, Mubashar Hussain, Cao Ning and Yang Yuesuo1. (2019). Scholar Journal of Applied Sciences and Research. Sch J Appl Sci Res. 2: 2

8. Cakmak, I. (2008). Enrichment of cereal grains with zinc: Agronomic or genetic biofortification? Plant and Soil, 302: 1-17.

9. Cakmak, I., Kalayci, M., Kaya, Y., Torun, A.A., Aydin, N. and Wang, Y. (2010a). Biofortification and localization of zinc in wheat grain. Journal of Agricultural \& Food Chemistry, 58: 9092-9102.

10.Cakmak I., Pfeiffer W.H. and MccLaffertY B. (2010). Biofortification of durum wheat with zinc and iron. Cereal Chemistry, 87: 10-20.

11.Cakmak, I. and U.B. Kutman. (2018). Agronomic biofortification of cereals with zinc: a review. European Journal of Soil Science, 69: 172-180

12.Carla S. Santos, Susana M. P. Carvalho, Manuela M. Pintado and Marta W. Vasconcelos. (2019). Preserving the nutritional quality of crop plants under a changing climate: importance and strategies. Plant and Soil, $443: 1$ $-26$

13.Chaudhary, D.P., Kumar, A., Sapna, Mandhania, S., Srivastava, P. and Kumar, R.S. (2012). Maize as fodder-An Alternative Approach. Directorate of Maize Research, New Delhi, pp. 32.

14.Chavali Kameswara Rao and Seetharam Annadana. (2017). Nutrient Biofortification of Staple Food Crops: Technologies, Products and Prospects. Phytonutritional Improvement of Crops, First Edition. (C) 2017 John Wiley \& Sons Ltd.

15.Connorton, J.M., Jones, E.R., Rodriguez-Ramiro, I., Fairweather-Tait, S., Uauy, C. and Balk, J. (2017). Wheat vacuolar iron transporter TaVIT2 transports $\mathrm{Fe}$ and $\mathrm{Mn}$ and is effective for biofortification. Plant Physiology, 174: 2434-2444.

16.Creswell J Eastman, M. D. and Michael B Zimmermann, M. D. (2018). lodine Deficiency Disorders. Endotext, February 6

17.Dahiya, S., Chaudhary, D., Jaiwal, R., Dhankher, O. and Singh, R. (2008). Elemental biofortification of crop plants. In: Jaiswal P, Singh R, Dhankar OP (eds) Plant membrane and vacuolar transporters. CABI International, Wallingford/Cambridge, pp. 345-371.

18.Dass, S. (2013). Maize and its diversified uses, In Maize production systems for improving resource-use efficiency and livelihood security, Eds., Kumar, Ashok, Jat, S. L., Kumar, Ramesh, Yadav, O.P., Directorate of Maize Research, pp. 1-3.

19.Denbow, DM., Grabau, EA., Lacy, GH., Kornegay, ET., Russell, DR. and Umbeck, PF. (1998). Soybeans transformed with a fungal phytase gene to improve phosphorus availability for broilers. Poult. Sci., 77:878-81

20.Dennis D. Miller, Ross M. Welch. (2013). Food system strategies for preventing micronutrient malnutrition. Food Policy, 42: 115-128

21.Devendra Kumar Yadava, Firoz Hossain and Trilochan Mohapatra. (2018). Nutritional security through crop biofortification in India: Status \& Future Prospects. Indian J. Med Res., 148: 621-631.

22.Dhaliwal, S.S., Sadana, U.S., Khurana, M.P.S., Dhadli, 
H.S. and Manchanda, J. S. (2010). Enrichment of rice grains through ferti-fortification. Indian Journal of Fertilizer, 6 (7): 28-35.

23.Drakakaki, G., Marcel, S., Glahn, RP., Lund, EK. and Pariagh, S. (2005). Endosperm-specific coexpression of recombinant soybean ferritin and Aspergillus phytase in maize results in significant increases in the levels of bioavailable iron. Plant Mol. Biol., 59: 869-80

24.Fang, Y., Wang, L., Xin, Z., Zhao, L., An, X. and Hu, Q. (2008). Effect of foliar application of zinc, selenium, and iron fertilizers on nutrients concentration and yield of rice grain in China. Journal of Agriculture Food and Chemistry, 6(56):2079-84. doi:10.1021/jf800150z

25.Ferrandon $M$ and Chamel AR (1989). Cuticular retention, foliar absorption and translocation of $\mathrm{Fe}, \mathrm{Mn}$ and $\mathrm{Zn}$ supplied in organic and inorganic form. J. Plant Nutr., 11: 247-263.

26.Firoz Hossain, Konsam Sarika, Vignesh Muthusamy, Rajkumar Uttamrao Zunjare, and Hari Shanker Gupta. (2019). Quality Protein Maize for Nutritional Security. https://www.researchgate.net/publication/331127385. DOI: 10.1007/978-3-030-04609-5_11

27.Francesco Burchi, Jessica Fanzo and Emile Frison. (2011). The Role of Food and Nutrition System Approaches in Tackling Hidden Hunger. Int $J$ Environ Res Public Health, 8(2): 358-373.

28.Flora Josiane Chadare, Rodrigue Idohou, Eunice Nago, Marius Affonfere, Julienne Agossadou, Toyi Kévin Fassinou, Christel Kénou, Sewanou Honfo, Paulin Azokpota, Anita R. Linnemann and Djidjoho J. Hounhouigan. (2019). Conventional and food $\square$ to $\square$ food fortification: An appraisal of past practices and lessons learned. Food Sci Nutr. 7(9): 2781-2795.

29.Frossard, E., Bucher, M., Machler, F., Mozafar, A. and Hurrell, F. (2000). Potential for increasing the content and bioavailability of $\mathrm{Fe}, \mathrm{Zn}$ and $\mathrm{Ca}$ in plants for human nutrition. Journal of the Science of Food and Agriculture, 80: 861-879.

30.Gannon, B., Kaliwile, C., Arscott, S. A., Schmaelzle, S., Chileshe, J., Kalungwana, N., Mosonda, M., Pixley, K., Masi, C. and Tanumihardjo S. A. (2014). Biofortified orange maize is as efficacious as a vitamin A supplement in Zambian children even in the presence of high liver reserves of vitamin A: a community based, randomized placebo-controlled trial. American Journal of Clinical Nutrition, DOI:10.3945/ajcn.114.087379.

31.Graham Lyons. (2018). Biofortification of Cereals with Foliar Selenium and lodine Could Reduce Hypothyroidism. Front Plant Sci., v.9. doi: 10.3389/fpls.2018.00730

32.Graham H. Lyons and I. Cakmak. (2015).Agronomic Biofortification of Food Crops with Micronutrients. https:// www.researchgate.net/publication/281572357.

33.Graham, R.D., R.M. Welch, and H.E. Bouis. (2001). Addressing micronutrient malnutrition through enhancing the nutritional quality of staple foods: Principle, perspectives and knowledge gaps. Advances in Agronomy, 70:77142.

34.Gregorio, GB., Senadhira, D., Htut, H.. and Graham, RD. (2000). Breeding for trace mineral density in rice. Food Nutr Bull 21:382-386

35.Gyana R. Rout and Sunita Sahoo. (2015). Role of iron in plant growth and metabolism. Reviews in Agricultural Sciences, 3: 1-24

36. Gupta, Hari Shankar, Hussain, Firoz and Muthusamy, Vignesh (2015). Biofortification of Maize - An Indian perspective. Indian J. Genetics, 75 (1): 1-22

37.He, W., Shohag, MJ., Wei, Y., Feng, Y. and Yang, X. (2013). Iron concentration, bioavailability, and nutritional quality of polished rice affected by different forms of foliar iron fertilizer. Food Chemistry, 141(4):4122-6. Doi: 10.1016/j. foodchem.2013.07.005

38.Imran, M. and Rehim, A. (2017). Zinc fertilization approaches for agronomic biofortification and estimated human bioavailability of zinc in maize grain. Arch Agron Soil Sci., 63:106-116. https://doi. org/10.1080/036 503 40.2016.1185660

39.Imran, M., Kanwal, S., Hussain, S., Aziz, T. and Maqsood, MA. (2015). Efficacy of zinc application methods for concentration and estimated bioavailability of zinc in grains of rice grown on calcareous soil. Pak J Agric Sc., i 52:169-175. http://www.pakjas.com.pk

40.Imran, M., Rehim, A., Hussain, S., Zafar ul Hye, M. and Rehman, HU. (2016). Efficiency of Zinc and phosphorus applied to open-pollinated and hybrid cultivars of maize. Int J Agric Biol 18: 1249-1255.

41.James M. Connorton and Janneke Balk. (2019). Iron Biofortification of Staple Crops: Lessons and Challenges in Plant Genetics. Plant Cell Physiol., 60(7): 1447-1456

42.Krezel, A. and Maret, W. (2016). The biological inorganic chemistry of zinc ions. Archives of Biochemistry \& Biophysics. 611, 3-19.

43.Kutman, U.B., Yildiz, B., Oztruk, L. and Cakmal, I. (2010). Biofortification of dutrum wheat with zinc through the soil and foliar application of nitrogen. Cereal Chem., 87: 1-9.

44.Lal, R. (2009). Soil degradation as a reason for inadequate human nutrition. Food Security, 1: 45-57.

45.Meenakshi, J., Johnson, N., Manyong, V., Degroote, H., Javelosa, J., Yanggen, D., Naher, F., Gonzalez, C., Garcia, J. and Meng E. (2010). How cost-effective is biofortification in combating micronutrient malnutrition? An ex-ante assessment, World Development, 38 (1): 64-75.

46. Garg, Monika, Natasha Sharma, Saloni Sharma, Payal Kapoor, Aman Kumar, Venkatesh Chunduri, and Priya Arora. (2018). Biofortified Crops Generated by Breeding, Agronomy, and Transgenic Approaches Are Improving Lives of Millions of People around the World. Frontiers in Nutrition, . V.5: 12.

47.Mónica Liliana García-Bañuelos, Juan Pedro Sida-Arreola and Esteban Sánchez. (2014). Bio forti fication - promising approach to increasing the content of iron and zinc in staple food crops. J. Elem. s. 865-888. DOI: 10.5601/ jelem.2014.19.3.708

48. Maqbool, Muhammad Amir and Beshir, AbduRahman (2019). Zinc biofortification of maize (Zea mays L.): Status and challenges. Plant Breeding. 138:1-28.

49.Ozkan, H., Brandolini, A., Torun, A., AltIntas, S., Ekerm, S., Kilian, B., Braun, HJ., Salamini, F. and Cakmak, I. (2007). Natural variation and identification of microelements content in seeds of Einkorn wheat (Triticum monococcum). Dev Plant Breed, 12:455-462

50.Peter Ranum, Juan Pablo Pena-Rosas and Maria Nieves Garcia-Casal. (2014). Global maize production, utilization, 
and consumption. Ann. N.Y. Acad. Sci,. 1312: 105-112

51.Pfeiffer, WH. and McClafferty, B. (2007). Harvest Plus: Breeding crops for better nutrition. Crop Science, 47: S88105.

52.Philip J. White1 and Martin R. Broadley. (2005). Biofortifying crops with essential mineral elements. Trends in Plant Science, 10 (12) : 586-593

53.Prasad, Rajendra, Shivay, Yashbir Singh and Kumar, Dinesh (2014). Agronomic Biofortification of Cereal Grains with Iron and Zinc. Advances in Agronomy, 125: 55-91

54.Rafael da Silva Messias, Vanessa Galli, Sergio Delmar dos Anjos e Silva, Manoel Artigas Schirmer and Cesar Valmor Rombaldi. (2013). Micronutrient and functional compounds biofortification of maize grains: Critical reviews in food science and nutrition, Dol: 10, 10408398. 2011. 649314.

55.Raut, N., Sitaula, B. K. and Bajracharya, R. M. (2010). Agricultural intensification: linking with livelihood improvement and environmental degradation in mid-hills of Nepal. Journal of Agriculture and Environmental Sciences, 11: 83-94.

56.Rehim A., Zafar-ul-Hye, M., Imran, M., Ali, M. and Hussain, M. (2014). Phosphorous and zinc application improve rice productivity. Pak. J. Sci., 66:134-139

57.Roman Nissar, R. Zahida, R.H. Kanth, Ganai Manzoor, Raheel Shafeeq, H. Ashaq, R. Waseem, Raies A Bhat, M.Anwar Bhat and Sheikh Tahir. (2019). Agronomic biofortification of major cereals with zinc and iron $-\mathrm{A}$ review. Agricultural Reviews, 40 (1): 21-28

58.Sarwar, N., Ishaq, W., Farid, G., Shaheen, MR., Imran, M., Geng, M. and Hussain, S. (2015). Zinc-cadmium interactions: impact on wheat physiology and mineral acquisition. Ecotoxicol Environ Saf. 122: 528-536

59.Singh, S.P., Patel, Chanchala Rani and Paikra, K.K. (2020). Integrated Nutrient Management: An Effective Approach for Sustainable Agriculture in Chhattisgarh: A Review. Int.J.Curr.Microbiol.App.Sci .,9(5): 1652-1662

60.Malhotra, Suresh K. (2017). Diversification in Utilization of Maize and Production. Department of Agriculture, Cooperation and Farmers Welfare Ministry of Agriculture and Farmers Welfare, Government of India. A Compendium, Vol 5: 49-57

61. Kumar, Sushil, Palve, Adinath, Joshi, Chitra, Srivastava, Rakesh K. and Rukhsar. (2019). Crop biofortification for iron $(\mathrm{Fe})$, zinc $(\mathrm{Zn})$ and vitamin A with transgenic approaches. Heliyon, 5(6): e01914.

62.Stein, A., Sachdev, H. and Qaim, M. (2006). Potential impact and cost-effectiveness of Golden Rice. Nature Biotechnology, 24:1200-1201.

63.Kumar, Sushil, Thirunavukkarasu, Nepolean, Singh, Govind, Sharma, Ramavtar, and Kulkarni, Kalyani S. (2015). Biofortification for Selecting and Developing Crop Cultivars Denser in Iron and Zinc. Nutrient Use Efficiency: from Basics to Advances, DOI 10.1007/978-81-322-21692_16.

64.Tanumihardjo, S. A., Anderson, C., Kaufer-Horwitz, M., Bode, L., Emenaker, N. J., Haqq, A. M., Satia, J. A., Silver H. and Stadler D. D. (2007). Poverty, obesity and malnutrition: an international perspective recognizing the paradox. Journal of the American Dietetic Association, 107: 1966-1972.

65.USDA. (2013). India- Grain and Feed Annual, USDA Foreign Agricultural Service, GAIN Report No. IN3012.

66.Velu, G. (2013). Biofortification strategies to increase grain zinc and iron concentrations in wheat. $J$ Cereal Sci., 59 (3):365-372

67.White, P.J. and Broadley, M.R. (2011). Physiological limits to zinc biofortification of edible crops. Frontier Plant Science, 2: 80.

68.Yuan, L., Wu, L., Yang, C. and Quin, LV. (2013). Effects of iron and zinc foliar applications on rice plants and their grain accumulation and grain nutritional quality. Journal of the Science of Food and Agriculture, 93(2):254-61. doi:10.1002/jsfa.5749

69.Yang, X., Tian, X., Gale, W., Cao, Y., Lu, X., Zhao, A., (2011). Effect of soil and foliar zinc application on zinc concentration and bioavailability in wheat grain grown on potentially zinc-deficient soil. Cereal Res. Commun. 39: 535-543.

70.Zhu, C., Naqvi, S., Gomez-Galera, S., Pelacho, AM., Capell, T. and Christou P. (2007). Transgenic strategies for the nutritional enhancement of plants. Trends in Plant Science, 12:548-55

71.Zhou, C.Q., Zhang, Y.Q., Rashid, A., Ram, H., Savasli, E. and Arisoy, R.Z. (2012). Biofortification of wheat with zinc through zinc fertilization in seven countries. Plant and Soil, 361: 119-130 